\title{
The Metropolitan Life in German Artists' Legacy of the Pre-war and Interwar Period
}

\author{
Maria Belikova ${ }^{1, *}$
}

\begin{abstract}
${ }^{1}$ Department of Modern and Contemporary Western Art, State Institute for Art Studies (SIAS), Moscow, Russia *Corresponding author. Email: belikovamaria@yandex.ru
\end{abstract}

\begin{abstract}
Urban life became one of the dominant themes in Weimar art, as a city had been the main living space for a human of the XX century. Being one of the main centres of political and cultural life in Germany, Berlin cannot but attracted artists from all over the country. The article compares the peculiarities of perception of the metropolitan life by expressionists and the representatives of new objectivity. If for the expressionists it was important to look at urban environment in a new way, to reflect its vitalism and dynamism, the new objectivity artists sought to capture the facts of social reality, taking a sober look at the surrounding environment and revealing its most unattractive features. Nevertheless, both movements contributed to the development of new vision of city space, having produced thousands of works devoted to urban issues.
\end{abstract}

\section{Keywords: German art, Expressionism, new objectivity, Berlin urban life, Weimar artists}

\section{INTRODUCTION}

Sociologist Max Weber once noted that the achievements of modern painting would not have been possible without the emergence of metropolises life in which proceeds according to its own laws and is radically different from the one that takes place in small towns [1]. Setting a rapid pace of life, around-the-clock existence, providing incredible opportunities for work and leisure, big cities accumulate scientific and technological potential and attract millions of people not only at the local level but also at the global one.

The depiction of the urban landscape has a long historical tradition in German visual art. At the beginning of the XX century, with the intensive development of the urban environment and the emergence of metropolises, the theme of the city was gradually gaining prominence, becoming one of the main leitmotifs in both German and European fine arts. By 1910, the population of Berlin had exceeded 3 million inhabitants [2], and it could have already been considered as one of the largest capitals in Europe. By the 1920s, the so-called "Greater Berlin" had been formed, the territory of which included, in addition to the historical centre, the surrounding suburbs (Charlottenburg, Rixsdorf, Schönenberg, etc.). The population of Greater Berlin numbered more than 4 million denizens in the early 1920s [3]. Berlin joined the race for the right to be called the world capital with Paris, London and New York, and it was without no doubt the epicentre of all events in the country. As a rule, almost all German artists wanted to visit the capital at least once, and some of them stayed there for a long time, being fascinated by the unique atmosphere of the city and the dynamism of its life. The purpose of the article is to study the peculiarities of perception of the metropolitan life by German artists in the pre-war and interwar period.

\section{EXPRESSIONISM AND A NEW PERCEPTION OF URBAN LIFE}

The call to study and reflect urban life came from the famous expressionist Ludwig Meidner in 1914 on the eve of the First World War. In his prominent essay "An introduction to painting the metropolis" [4] Meidner admits his love for big cities and urge the younger generation of artists to keep up with the times, reflecting in their works all the intricacies of urban life through the use of geometric forms, diagonal lines and bright colours. "Let's write what is close to us, our city world! Wild streets, the elegance of suspended iron bridges, gas meters that can be seen in the white clouds of mountains, the bright colours of buses and trains, the flutter of telephone wires (are they not akin to music?), harlequinades of billboards and finally the night... the night of the big city..." [5]. Thus, Meidner's words were more relevant than ever for the post-war period, when urban themes became one of the dominant themes in the art context of the $1920 \mathrm{~s}$

In his canonical self-portrait "The city and I" (Fig. 1) of 1913, Meidner deals with the theme of the city remaining within the framework of expressionist aesthetics, and in fact he conveys his personal, subjective impressions and experiences, as if 
prophetically anticipating the coming apocalyptic events. Expressionists were among the first in Germany who approached the theme of the city from the point of view of exploring the multifaceted experience of urban existence. Before the appearance of Expressionism on the German art scene there was no movement that would rely directly on personal experience of urban existence.

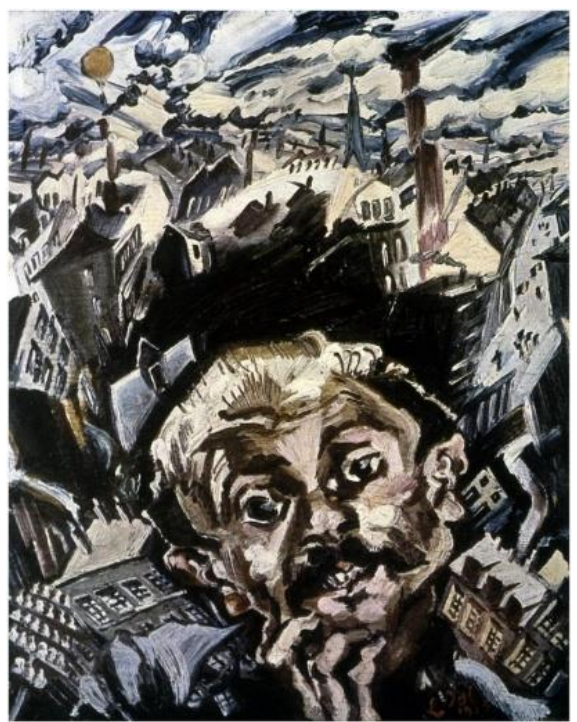

Fig. 1. Meidner. The city and I. 1913. Oil on canvas. The Jewish Museum. Frankfurt am Main.

Researcher Jost Hermand writes: "From the very beginning, expressionism was a modernist, avant-garde art of the metropolis, which is not conceivable without its entourage-art cafes, bohemian surroundings, small publishing houses. Despite the connection of expressionism with biological mystical, utopian primordial principles, it became the first actual art of the big city in Germany, finding its natural centre in Berlin..." [6].

The expressionists conveyed in their paintings, in the words of Benjamin, the "shock effects" of modernity [7]. Artists tried to capture the spirit of urban life in urban cafes, cabarets, and, of course, directly on the streets of the city. In some sense, the artists took on the role of flaneurs - a gradually vanishing type of personality who studied the labyrinths of urban space and the physiognomy of the crowd. However, if Baudelaire's flaneur was distanced from the crowd, preferring to observe from afar over the tumultuous life around them, the expressionists were actively involved in the events taking place and shifted the centre of observation from the outside to the inside, that is, they began to use all the leisure opportunities that were popular with the masses (Fig. 2).

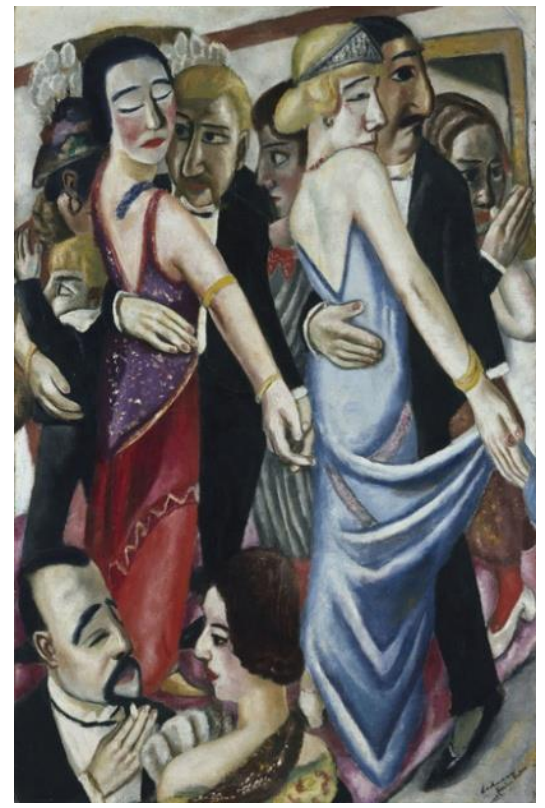

Fig. 2. M. Beckmann. Dance in Baden-Baden. 1923. Oil on canvas. Los Angeles County Museum of Art.

If the impressionists sought to capture on their canvases the light that constructs, in fact, the depicted objects, the expressionists drew attention to the fact that in reality "we do not perceive light everywhere in nature" [8]. As a result, light so "cuts objects into parts" [9] that the surrounding space is perceived by the psyche as a struggle of light and darkness. Meidner proposed to depict the city from a variety of displaced points of view, which, in his opinion, most reliably conveys the feeling of the dynamic atmosphere of the metropolis. Finally, straight lines are needed to demonstrate "what triangles, squares, right angles, and circles are rush out at us in the streets" [10]. Each expressionist, of course, took a different approach to the representation of the city, and Meinder's recommendations did not become a universal practical guide, although they influenced to some extent the next generation of artists - G. Grosz, K. Felixmüller, who often visited his Berlin studio. 


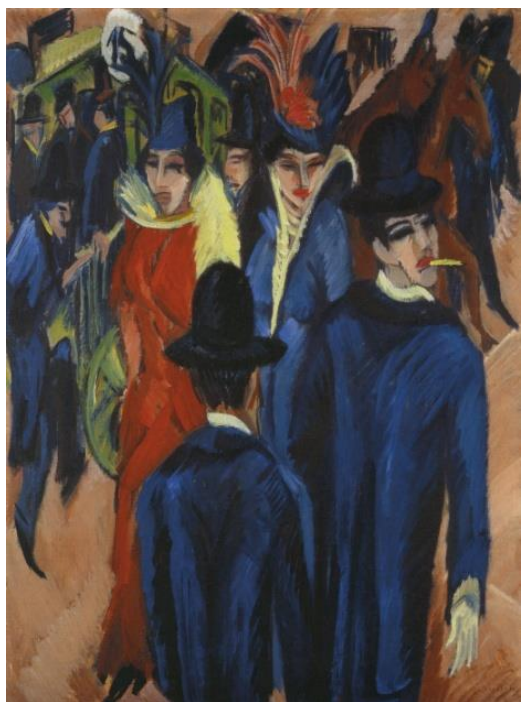

Fig. 3. E. L. Kirchner. Berlin street scene. 1914. Oil on canvas. Neue Galerie, New York.

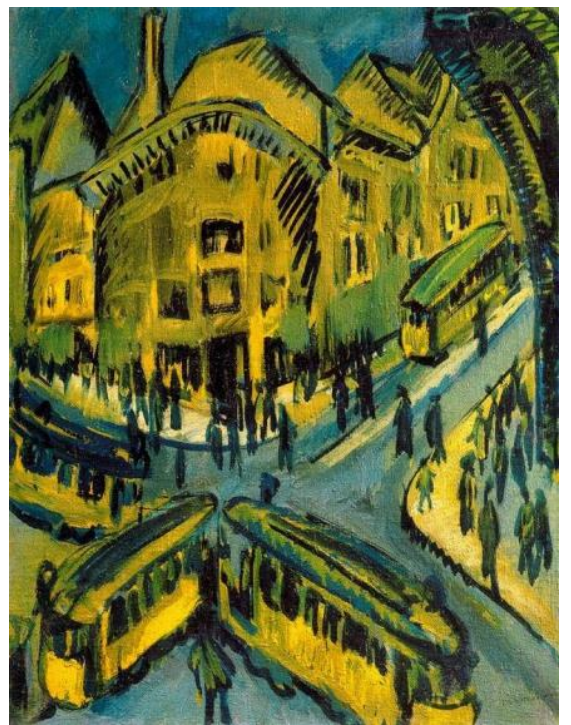

Fig. 4. E. L. Kirchner. Nollendorfplatz. 1912. Oil on canvas. Stadtmuseum Berlin.

E. L. Kirchner' cycle devoted to Berlin is a kind of manifestation of vital forces, released primal instincts that pervade urban space. The architectural appearance of the streets here recedes into the background, leaving room for interpersonal interactions of passers-by, characterized by heightened sensuality (Fig. 3). Most of his works, dedicated to the metropolitan life, he created in the years 1911-14 during his stay in the capital. Critic Kurt Glaser wrote: "No artist has felt the metropolis of Berlin during the last pre-war years so strongly, with all the fibers of his soul, as did Kirchner" [11]. Researcher D. Bartman called the paintings of this cycle "psychograms of urban life" [12]. This cycle of Kirchner's works is characterized by common compositional and technical principles: an inverted horizon line, the construction of angular forms and distorted proportions that seem to stretch under the influence of centripetal diagonal lines (Fig. 4). These "lines of force", as the artist himself called them, were borrowed by him from wood engravings, a common technique among expressionists, designed to convey the pulsating energy of the city.

\section{NEW OBJECTIVITY AND THE DARK SIDE OF METROPOLITAN LIFE}

Stylistic features and worldview of the new objectivity artists are fundamentally different from the works of expressionists: returning to the realistic tradition, academic drawing on the backdrop of the panEuropean trend of "return to the order", they turned into a kind of chronicles of urban life. Their heritage includes portraits of people against the background of urban views, various genre scenes taken from everyday Berlin life, many urban and industrial landscapes of Berlin and its surroundings, as well as almost monumental symbolic paintings representing the life of the capital, with all its "splendours and miseries": leisure activities in nightclubs, jazz performances, expensive department stores and restaurants, and at the same time social inequality, crime, prostitution and poverty.

If the majority of the expressionists were interested in the inner world of man, religious visions, nonWestern cultures, children's drawings and even the art of the insane, a new generation of artists, who saw the horrors and repercussions of the Great War, was interested in the surrounding environment and was willingness to reflect everyday, sometimes ugly reality in their works. In this regard, the theme of the city becomes one of the central motifs for artists of the left wing of the new objectivity, or, as their contemporaries called them, the verists [13].

It should be noted that Georg Grosz, one of the main representatives of Berlin's artistic life in the 1920s, as already mentioned, visited Meidner's studio many times [14] and, despite his negative attitude to expressionism as a phenomenon, he apparently adopted Meidner's enthusiasm for depicting modern urban life. This is especially evident in his early works ("Germany, a winter's tale" (1918), "The Funeral, dedicated to Oskar Panizza" (1918), "The Big City" (1917) (Fig. 5), "Metropolis" (1917), (Fig. 6), where the artist conveys the chaotic and dynamic life of Berlin through the use of a fractional composition, refuse of a single perspective, the displacement of front and back and the overlay of characters and objects. These works are dominated by shades of red and ochre, which capture the atmosphere of irreal chaos that prevailed in public and political life in Weimar Germany. These paintings were influenced not only by expressionists, 
but also by Italian futurists, who also sought to reflect the dynamics of big city life in their works.

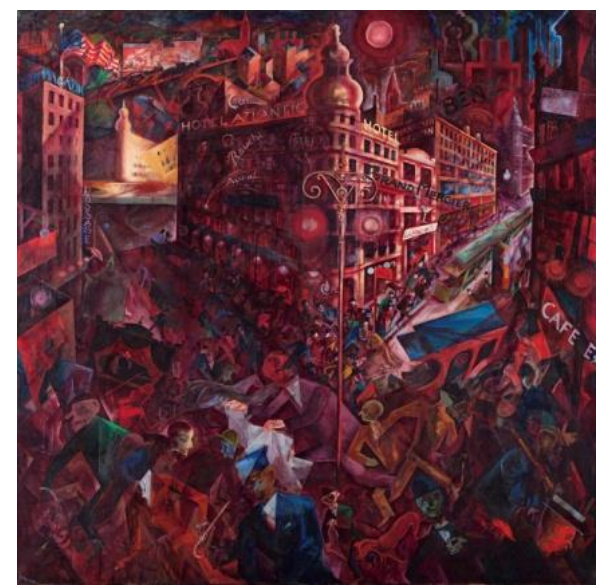

Fig. 5. Grosz. The Big city. 1916-17. Oil on canvas. ThyssenBornemisza Museum, Madrid.

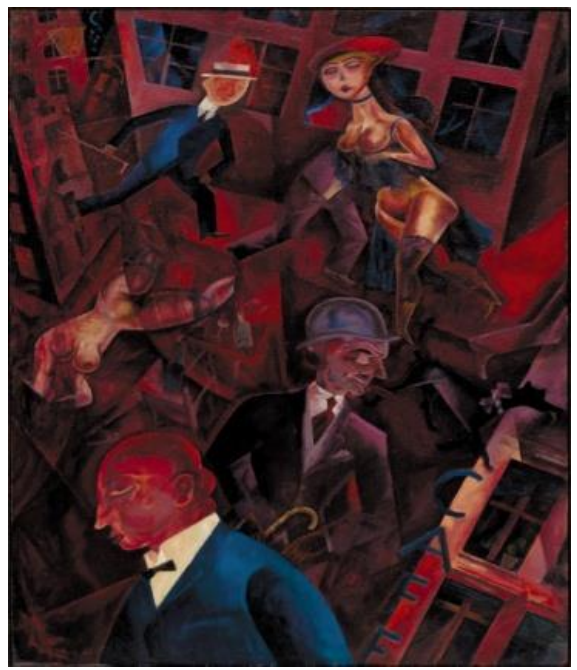

Fig. 6. G. Grosz. Metropolis. 1917. Oil on cardboard. The Museum of Modern Art, New York

In his later works on Berlin, Grosz refuses this style, making compositions of paintings more balanced and the colour scheme more restrained. At the same time, the criticism concerning political and social spheres of public life increased in his works. In the early 1920s, under the influence of Italian metaphysical painting, he created a series of works where the main action takes place against the background of the dead artificial city. Italian metaphysical painting attracted the artist, since both G. de Chirico and C. Carra also address to the image of empty city full of mysterious objects using strict geometry of forms and reliance on drawing [15]. In this cycle, Berlin appears as a city whose streets are deserted and built up with functionalist buildings. For example, in the lost watercolours "Berlin C" (Fig. 7) and "Jakobstraße" (Fig. 8), weak-willed residentspuppets wander aimlessly and lost along the identical buildings. Here, Grosz hints about the costs of a mass industrial society in which conformism and manipulations by the authorities flourish.

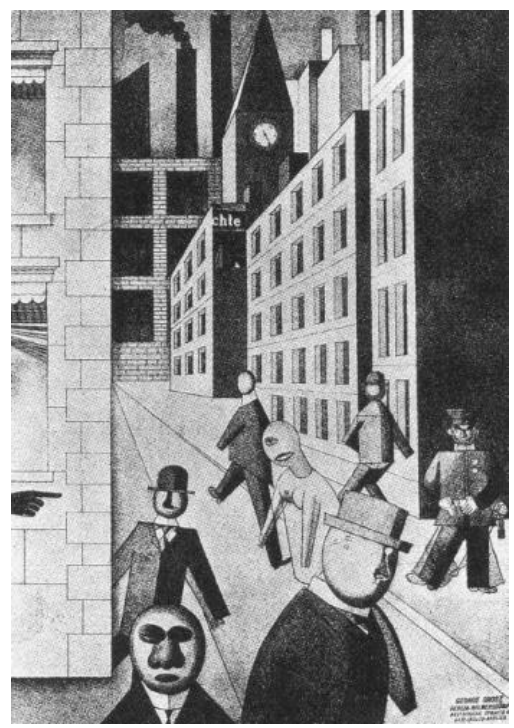

Fig. 7. G. Grosz. Berlin C. 1920. Paper, watercolor. Lost.

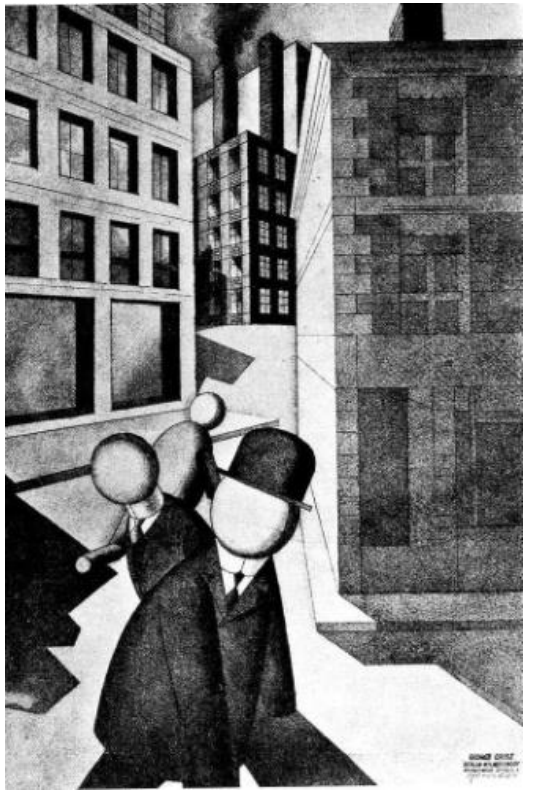

Fig. 8. G. Grosz. Jakobstrasse. 1920. Paper, watercolour. Lost.

In the painting "Untitled" (Fig. 9), Grosz creates a kind of monument to a resident of the metropolis, embodying it in a creepy, impersonal and limb-less torso of a mannequin, which is located on a pedestal in the middle of the empty street. Thus, he accentuates the problem of deindividualization of a person in the modern city. 


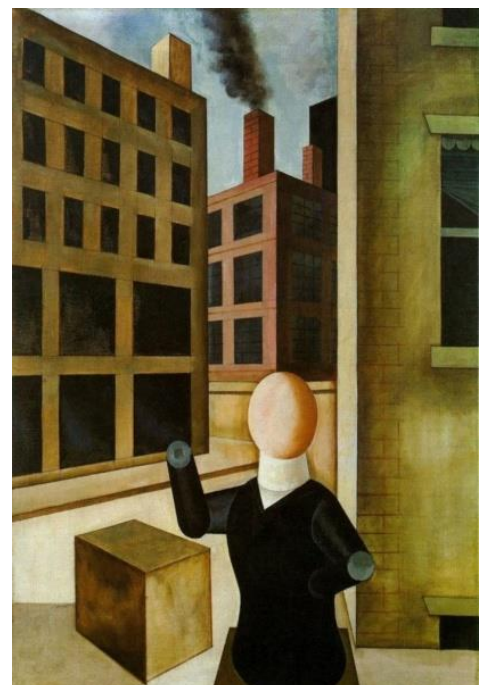

Fig. 9. G. Grosz. Untitled. 1920. Oil on canvas. Dusseldorf, Art collection of the land of North Rhine-Westphalia.

The plot of another painting "Street scene" (Fig. 10) takes place not in an abstract place in Berlin, but on one of its main streets - Kurfürstendamm. Here, Grosz's left-wing views were clearly manifested through criticism of the bourgeois way of life and social injustice. Near the entrance to an expensive store stands a disabled war veteran, passing by with people who pay no attention to him. The style of the painting is sustained in a more realistic tradition, although it is not without grotesque - Grosz's remarkable stylistic feature.

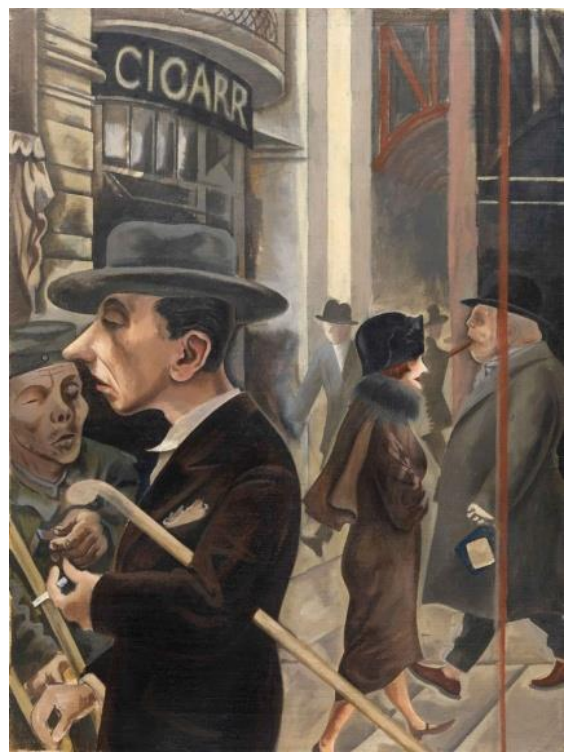

Fig. 10. G. Grosz. The street scene. 1925. Oil on canvas. ThyssenBornemisza Museum, Madrid.

Grosz's another work - "Grey day" (Fig. 11) again refers to the routine of Berlin urban life: an official goes to work, dressed in a business suit with a bowler hat on his head; a war invalid in military uniform, with a crutch and a drooping head wanders aimlessly nearby; a worker in uniform with a shovel with an impersonal face goes to the factory, whereas a profiteer in a black coat looks around the corner, waiting for customers. It is very symbolic that the official in the foreground is separated from other characters in the background by brickwork - a straightforward hint on social inequality. Against the background, one can see the factories and chimneys - essential attributes of the industrial world. Grosz shows Berlin typical denizens of the 1920s, thus denouncing the socio-economic problems of his time.

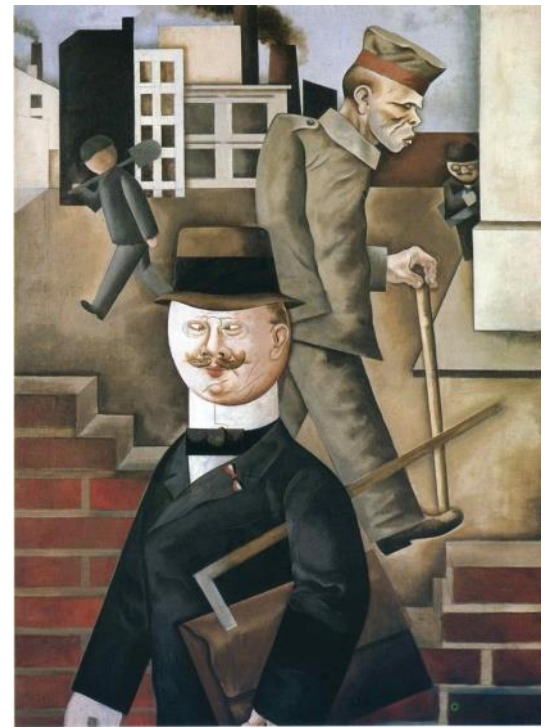

Fig. 11. G. Grosz. Grey day. 1921. Oil on canvas. Berlin National Gallery.

Grosz was not the only artist who deliberately created works with political bias to reveal the imbalances in social development, to attract viewers to the topical problems of the present. In this connection, it is impossible not to mention the famous Otto Dix' $s$ triptych "Metropolis" (Fig. 12), which he created on the eve of his departure from Berlin to Dresden, where he was offered a position as a professor at the local academy of arts. This triptych can be considered as artist's homage to Berlin, a city with which he had a complex love-hate relationship. This painting, which has become one of the most important works of the artist, can be regarded as the quintessence of Dix's views on Berlin life of the 1920s. Dix deliberately chose the form of the triptych, which is traditionally associated with religious painting, in order to expand the plot in a simultaneous development and thus reveal all the contradictions of the modern era. Dix refers to the old masters technique, meticulously drawing the smallest details of objects and characters. The central panel depicts a trendy nightclub where musicians play jazz and elegant couples dance carefree and cheerfully. Dix also shows a new type of woman dancing alone, 
dressed in fashion, with a short haircut and provocatively open dress. On the other two panels street scenes take place simultaneously with the action on the central panel. They depict the dark side of Berlin nightlife, with prostitutes walking the streets and crippled war veterans. Both prostitutes and disabled war veterans are social outsiders, those who live below the poverty line and nobody cares about them. The triptych shows a sharp criticism of social inequality and the artist's reproach towards the state, which is unable to solve these problems. The growth of prostitution in Berlin was unprecedented in the interwar period, which was reflected in the literature and cinema of the period in question. As for the disabled, more than 1.5 million people across the country were officially recognized by the state as war invalids [16], and therefore a disfigured veteran, with amputated limbs, became a distinctive "attribute" of Weimar Germany.

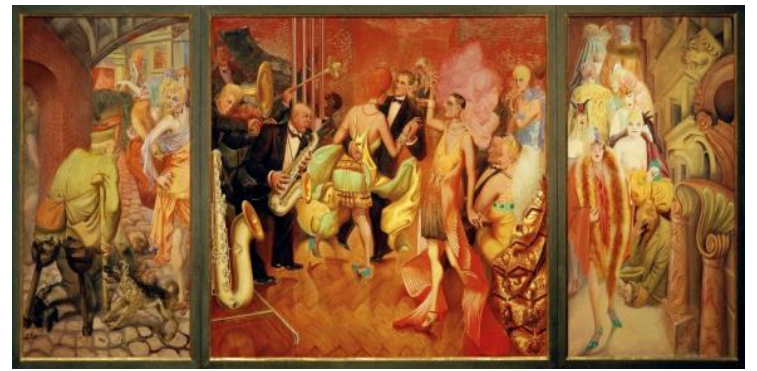

Fig. 12. O. Dix. Metropolis. 1927-28. Wood, distemper. Kunstmuseum Stuttgart.

In this work, the image of the city consists of those contradictions that underlay Berlin urban development during the interwar period: on the one hand, it was the era of the "roaring twenties", with a varied nightlife and advanced leisure facilities, but on the other - a period of severe economic crisis, rising unemployment, prostitution, social insecurity. Dix interprets the urban space in a very theatrical way in the spirit of academic painting: on the central panel on the right one can see an artificial curtain, while on the left and right folds there are arches and bizarre architectural baroque elements, which also serve as a backstage, fringing the composition.

Still, it cannot be concluded that Dix had an extremely negative attitude towards Berlin and its nightlife. It is well known that the artist himself was an active regular in nightclubs, loved jazz, collected music records, enjoyed dancing and even participated with his wife in dance competitions [17], in other words he was an organic part of mass culture in the 1920s. In this triptych manifested Dix's admiration for the turbulent nightlife of the metropolis, and at the same time the bitter awareness of the fact that a carefree life is a kind of illusion and flight from real problems. As a true artist, Dix rises above the ordinary consciousness, accustomed to divide everything into black and white, and creates a work that reflects all the contradictions of his era, and the triptych itself thus acquires an ambivalent sound.

New objectivity graphics dedicated to Berlin is also remarkable: artists' sketches reflect everyday scenes snatched from the numerous stream of events, as well as depict a particular urban area. For example, in Karl Hubbuch's 1922 drawing "On the corner of Leipziger and Friedrichstraße" (Fig. 13) one can observe the central district of Berlin at the time of large-scale underground construction: in the foreground is a yawning pit from which iron structures - the rudiments of future rail tracks - can be seen. Thus, Hubbuch captured one of the many transformations that the capital was forced to undergo during the process of urbanzation. Benjamin described Berlin as a place where "the most significant changes are taking place, excavators and diggers are constantly working, and the ground trembles under their feet from their work..." [18]. Modernizing the city meant fencing off certain construction sites and creating inconvenience for the city's residents in exchange for promises of a better future. The development of infrastructure restricted the movement of passers-by and even dictated one way or another to bypass them. These traces of large-scale continuous urban construction in the form of restrictive signs, fences, and wooden platforms can be found in the works of many German artists from $\mathrm{H}$. Baluschek to $\mathrm{K}$. Hubbuch.

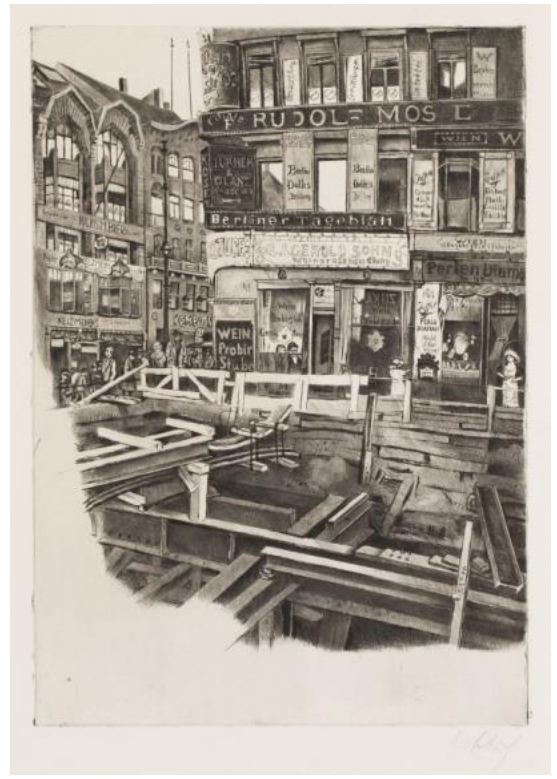

Fig. 13. K. Hubbuch. On the corner of Leipziger and Friedrichstraße. 1922. Graphite, paper. Location unknown.

Rudolf Schlichter's watercolour "Hausvogteiplatz" (Fig. 14) implies social criticism, which is difficult to grasp without knowing the specific historical realities of the period under study. The work shows a close-up of two women walking along the above-mentioned 
square, where male passers-by frown at them and look back. Historically since the middle of the XIX century this central Berlin district has been a location where many ateliers produced ready-made dresses for women [19]. Working for these ateliers was the only source of income for many female dressmakers, and therefore, with the sharp deterioration of the economic situation in the country, a significant number of them stopped receiving orders and were forced to move into the sphere of prostitution. Schlichter by depicting female characters in this district, hints to the viewer about the notorious status of these ladies. Taking into account the above mentioned, greedy views of the men surrounding them in the square become clear. To emphasize the hopelessness of the whole situation, the artist turns one of the closest lampposts to the viewer into a gallows, which eloquently symbolizes the death of the entire quarter, which hand been until recently a successful and prosperous district. The unreal pinkish glow of the sky and the simultaneous presence of the crescent moon and the planet Saturn gives the whole event an ominous character, hinting at a global malfunctioning of cosmic luminaries, predicting the decline of the world.

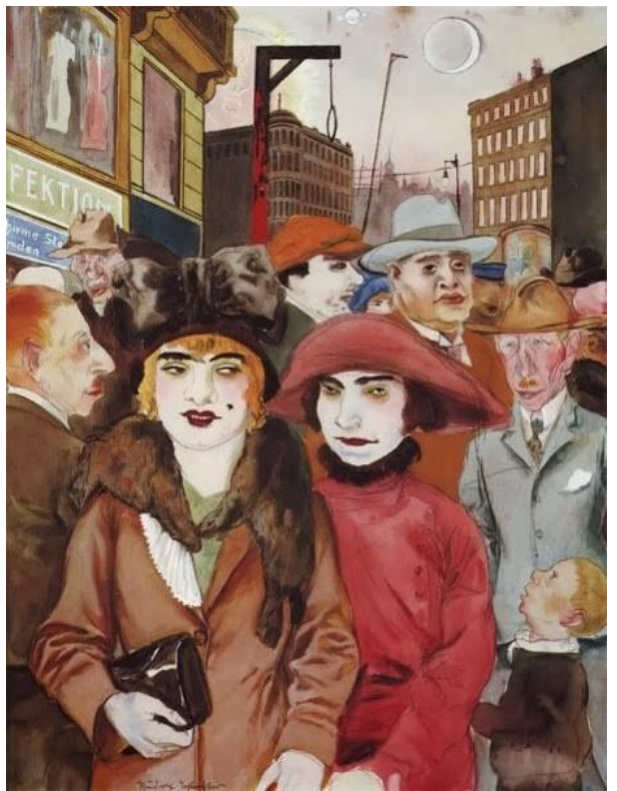

Fig. 14. R. Schlichter. Hausvogteiplatz. 1926. Watercolour, paper. Private collection.

Some artists specialized primarily in representing urban and industrial views, and Gustav Wunderwald was one of them. Having settled after the end of the First World War, like many other artists, in Berlin, he definitely falls under the definition of flaneurs. The urban space itself served as a source of inspiration for Wunderwald. It is noteworthy that the artist was attracted not to the famous and popular places of Berlin - central streets, squares, historical attractions, but rather to its suburbs and industrial areas, which had been built recently in the process of expanding the city.
In these unattractive and impoverished areas, which were inhabited mainly by factory workers and poor people, Wunderwald spent a lot of time making fullscale sketches, imbued with the atmosphere of harsh reality.

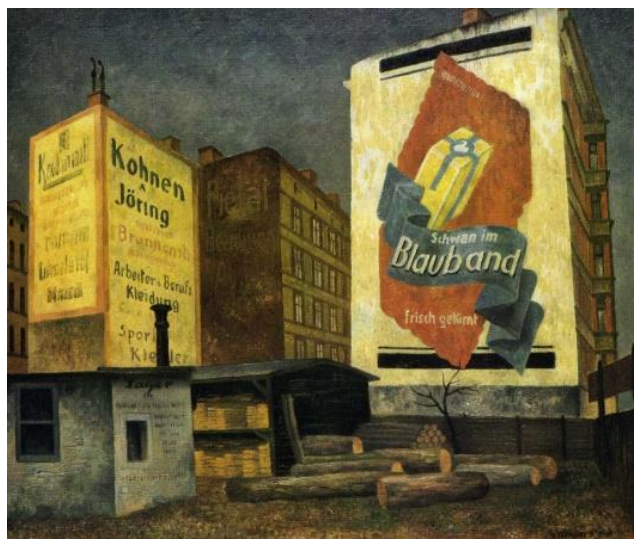

Fig. 15. G. Wunderwald. In Wedding. 1926. Oil on canvas. Berlin National Gallery.

He created dozens of paintings that depict the industrial areas of Berlin. For example, his 1926 work "In Wedding" (Fig. 15) shows one of these remote metropolitan areas: a lot of similar and rather dulllooking residential buildings, the walls of which are hung with huge advertising posters and signs. The artist chooses the lower point of view, in which residential buildings look monumental; the upper edge of one of them literally rests on the upper right side of the picture. In the foreground there are working rooms warehouses and workshops. Nature is almost completely absent here - only a small bare, leafless tree is lost against the background of massive logs lying in the warehouse and on the ground. Thus it becomes clear that nature is totally replaced here by human activity. The artist uses restrained and muted colours for buildings and the sky, which gets a lead-gray sinister shade - the result of continuous smog and unfavourable environmental conditions. Bright colour spots are used only when drawing billboards, creating a mismatch between bright, flashy ads and a dark, poor neighbourhood.

Other works by the author "Factory "Löwe and Co" (1927) (Fig. 16), "Factory in Weißensee" (1927) (Fig. 17) also show close-up of industrial buildings factories and plants, which also look monumental: massive walls and huge iron chimneys can be seen in front of the viewer, with smoke and steam coming out. One can hardly find image of humans in all these paintings, which gives the impression that the factories function without human intervention, on their own. 


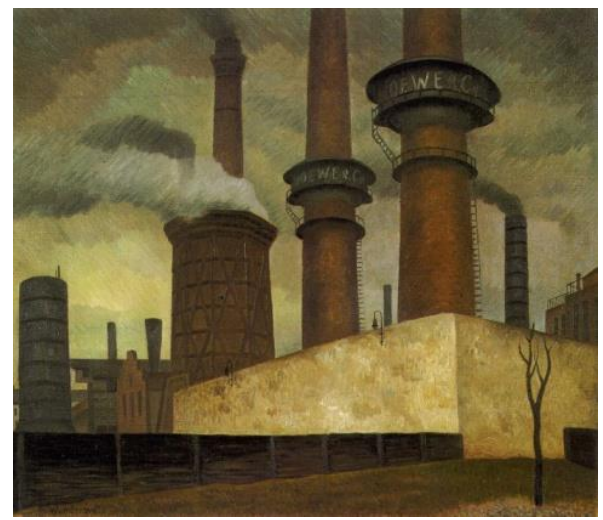

Fig. 16. G. Wunderwald. 1927. Oil on canvas. Factory "Löwe und Co". Berlin National Gallery.

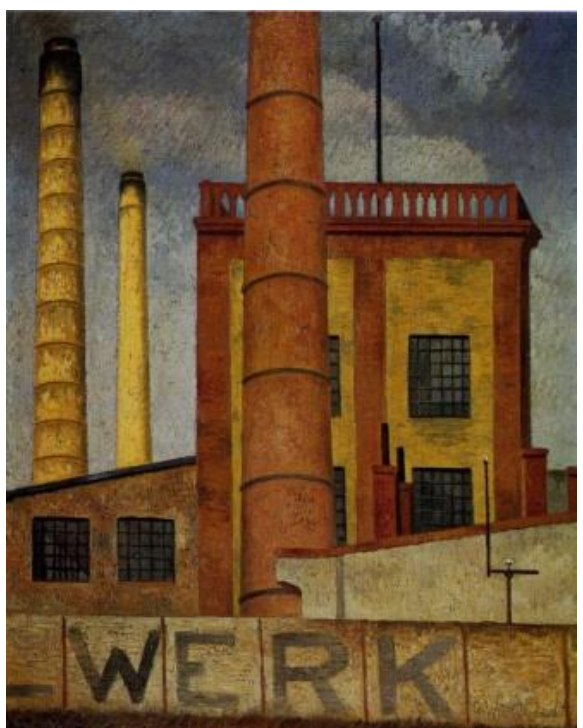

Fig. 17. G. Wunderwald. 1927. Factory in Weißensee Oil on canvas. Private collection.

Wunderwald does not romanticize the city, but tries to capture its objective characteristics, to show the other side of the metropolitan life, leaving out surface glamour of the central districts. Often his works imply critical dimension, since the industrial suburbs depicted by the author revealed even in the 1920s signs of an environmental disaster and were unsuitable for normal human life. The Berlin critic Paul Westheim, editor of the magazine "Kunstblatt" compared Wunderwald with the French painter Maurice Utrillo [20], who was also known primarily for his urban views. Westheim singles out Wunderwald as a new promising artist who has every chance to take the place of the main "painter of the new Berlin" [21].

\section{CONCLUSION}

Thus, the city becomes the main place of action in both Expressionism and new objectivity. If the expressionists sought to reflect the vitality of the urban environment and convey their own perception of the world in the city, the representatives of new objectivity chose a slightly different path. Political engagement and a strong interest in leftist theories about the transformation of the world on a fairer basis are typical features of the worldview of the artists under study. In their aspiration to reflect the objective reality and create topical art they could not pass by the metropolitan life, which is always an indicator of public sentiment. As a result, their heritage consist of hundreds of Berlin views, both its central districts and unsightly suburbs. The works analysed above reflect the life of representatives of different strata of the population from carefree entertainment of Berlin's bohemians to the miserable and inferior existence of socially vulnerable groups: war veterans, prostitutes, beggars, homeless. The search for objective truth is a core feature of Berlin artists' oeuvre, and therefore the aesthetics of the "ugliness" becomes the determining factor in the representation of urban environment, since the truth of life rises above the traditional artistic principle "art for art's sake".

\section{References}

[1] M. Weber, "Reports of the first German sociology forum", Tübingen. J. C. B. Mohr Publ. (Paul Siebeck), 1911, p. 98.

[2] D. Rowe, "Representing Berlin: Sexuality and the City in Imperial and Weimar Germany", Ashgate, 2003, p. 10.

[3] I. Whyte, D. Frisby, "Metropolis Berlin: 1880-1940", University of California Press, 2012, p. 2.

[4] L. Meidner, "An introduction to painting the metropolis" in: Kunst und Künstler, no. 5, 1914, pp. 312-314

[5] Ibid., p. 314.

[6] J. Klaus R. Scherpe "Unreality of a city. Representation of a metropolis between modern and postmodern", Rowolt, 1988, p. 66.

[7] W. Benjamin, "Baudelaire", Ad Marginem press, p. 75.

[8] Ibid., p. 312.

[9] Ibid.

[10] Ibid., p. 313.

[11] C. Haxthausen, H. Suhr, "Berlin: culture and metropolis", University of Minnesota Press, Minneapolis and Oxford, 1991, p. 4.

[12] K. Sanger, M. Ulrich, et. al., "The Conquest of the Streets. From Monet to Grosz", Hirmer Verlag, 2006, p. 289

[13] P. Schmidt, "German verists" in: Das Kunstblatt, 1924, vol 12, pp. 367-372.

[14] R. Heller, “Art in Germany (1909-1936). From Expressionism to Resistance: the Marvin and Janet Fishmann collection", Munich: Prestel Verlag, 1990, p. 261.

[15] I. Walter, "Realism: between Revolution und Reaktion (19191939)”, Berlin, München, 1981, pp. 20-25.

[16] D. Rowe, "Representing Berlin: Sexuality and the City in Imperial and Weimar Germany", Ashgate, 2003, p. 294.

[17] S. Funkenstein, "Fashionable Dancing: Gender, the Charleston, and German Identity in Otto Dix's "Metropolis" in: German Studies Review, 2005, vol. 28, no. 1, p. 24. 
[18] W. Benjamin, "The crisis of the novel" in: A. Döblin, "Berlin Alexanderplatz. A story about Franz Biberkopf", Moscow, Ladomir, 2011, p. 384.

[19] E. Roters, B. Schulz, "The city and I. Man and metropolis in German art of the XX century", Berlin, 1987, p. 174.

[20] E. Roters, "Gustav Wunderwald. Paintings - Drawings - Stage design", Berlin, 1982, p. 111.

[21] Ibid., p. 112. 